\title{
The Effect of Black Garlic Extract on Lipid Metabolism in Restraint Stressed Rats
}

Min-Jung Kang and Jung-Hye Shin*

\section{Namhae Garlic Research Institute, Namhae 668-812, Korea}

Received September 28, 2012 /Revised November 23, 2012 /Accepted November 26, 2012

\begin{abstract}
In order to determine the effective concentration, 2, 7, and 14 brix black garlic extracts (BGE) were fed to restraint stressed rats and the lipid metabolism was analyzed. The dietary intake of the 14 brix BGE-fed group was $547.64 \pm 13.99 \mathrm{~g} / 4$ weeks and it was significantly higher than that of the control group. The weight of all organs from the all BGE-fed groups showed no significant differences. While BGE concentration increased, BGE-fed groups tend to have low content of blood glucose. It was the lowest in the 14 brix BGE-fed group $(121.32 \pm 3.50 \mathrm{mg} / \mathrm{dl})$. Total cholesterol content was $54.54 \pm 1.63 \sim$ $65.84 \pm 2.61 \mathrm{mg} / \mathrm{dl}$. Total cholesterol content of the 14 brix BGE-fed group was the lowest and, in addition, lower than the normal group. Triglyceride content of serum showed the same tendency. HDL-cholesterol concentrations of the restraint stressed control (RSC) group were significantly higher than those of 7 and 14 brix BGE-fed groups. LDL and VLDL-cholesterol contents showed contrary results. GOT, GTP, and ALP activity of serum were lower when BGE concentration was higher. It is expected that BGE has a liver protective activity. In the liver, total lipids and triglyceride contents were significantly lower in BGE-fed groups than in the ISC group. However, total cholesterol content showed no significant difference between groups. TBARS content in liver of the 2 brix BGE-fed group was not significantly different than control, while 7 and 14 brix BGE-fed groups were lower than control. Glycogen content in the liver was only significantly lower in the 14 brix BGE-fed group than in the RSC group. Findings indicate that feed of BGE over 7 brix contributes to resolving the restraint-stressed rats by improving the lipid metabolism and liver protective activity.
\end{abstract}

Key words : Black garlic, restraint stress, cholesterol, GOT, GPT

\section{서 론}

현대인의 건강을 위협하는 주요 요인 중 하나는 체내의 활 성산소 또는 free radical로서 소위 성인병이라 불리는 여러 질병들의 원인이 되고 있는데 생체 내 정상적인 세포대사 과 정에서 생성되는 활성산소 및 free radical은 세포막의 손상, 지질산화, 단백질 분해 등을 초래함으로써 발병된다[1]. 산화 적 스트레스에 의하여 발생되는 활성산소는 생체 내에서 지질 과산화를 비롯하여 단백질, 탄수화물 및 DNA 산화에 의한 혈관순환계 질환, 암 발생 및 피부노화 등 다양한 질환의 발생 에 관련이 있는 것으로 보고되고 있고, 대체 의학 분야에서도 항산화제가 중요한 기능성 바이오 소재로 각광 받고 있다 $[2,20,21]$.

또 다른 건강 위협 요인으로 중 하나로 스트레스를 들 수 있다. 스트레스는 지속적인 육체의 피로 및 정신적 피로를 의 미하는데, 특별한 원인이 있는 경우도 있지만 없는 경우도 많 아 바쁜 생활, 지속적인 대인관계와 사회생활을 영위하여야 하는 현대인에게 있어서 아주 큰 건강위험 요인이 되고 있다

*Corresponding author

Tel : +82-55-860-8947, Fax : +82-55-860-8960

E-mail : whanbee@daum.net
[18]. 이러한 여러 건강위험 요인들로부터 건강을 지키기 위한 수단으로 질병이 발현된 이후에 취하게 되는 적극적인 치료와 는 차별화되는, 질병이나 위험요인으로부터 방어하기 위한 하 나의 수단으로 다양한 건강기능성 식품이 활용되고 있다. 치 료 보다는 예방의 개념으로서 섭취하게 되는 식품으로서 건강 기능성 식품이 다양하게 개발되고 있으며, 과거로부터 섭취되 어 오면서 오랜 세월 동안 그 기능성이 검증되어 온 식품들은 이들 건강기능성 식품 개발의 좋은 소재가 되고 있다.

대표적인 건강 기능성 식품 소재 중의 하나로 마늘을 들 수 있는데, 마늘(Allium sativum L.)은 백합과(Lilliaceae) 파속 (Allium)에 속하는 다년생 구근식물로 예로부터 우리 선조들 이 강장, 강정식품으로 널리 이용하여 왔다[11]. 근래에 들어 마늘에 대한 기능성이 부각되면서 마늘을 이용한 다양한 가공 식품이 제조되고 있는데, 가공을 통하여 마늘의 섭취편이성을 도모하고 기능성이 강화된 대표적인 개발품이 흑마늘이다. 흑 마늘은 생마늘의 매운맛과 특유의 자극취를 감소시키고 마늘 자체 성분의 반응에 따른 감미와 산미가 조화를 이루어 마늘 의 섭취를 용이하게 하는 장점이 있으며[26], 유리당의 함량이 증가되고 산도가 낮아져 새콤달콤한 독특한 맛을 갖게 된다 [5]. 흑마늘은 생마늘을 일정한 온도와 습도에서 장시간 숙성 시키는 과정 중 비효소적 갈변반응에 의해 흑색으로 변화되 
며, 이때 생성된 갈색화 반응 물질은 높은 항산화 활성을 가진 다[23]. 또한 폴리 페놀류의 함량 증가와 더불어 용출이 용이해 지면서 S-allyl-cysteine과 같은 수용성의 유황아미노산인의 함 량이 증가하여 생마늘에 비해 항산화능이 증가되고, 암 예방, 콜레스테롤 저하, 동맥경화 개선, 심장질환 예방, 산화스트레 스와 관련된 효과 및 항염증 활성 등의 효과를 가지는 것으로 알려져 있다[17,24].

흑마늘은 그대로 섭취하기도 하지만 흡수율을 높이고, 음용 의 편의성을 제공하고자 대부분이 추출물의 형태로 섭취되고 있다. 따라서 본 연구에서는 흑마늘 추출물의 농도를 달리하 여 급이한 후 구속 스트레스를 가한 흰쥐의 체내 지질대사를 중심으로 관찰함으로서 섭취된 구속 스트레스로 인한 체내 대사 변화 및 회복에 대한 흑마늘 추출물의 유효 농도를 확인 하기 위한 기초자료를 확보하고자 하였다.

\section{재료 및 방법}

\section{실험재료}

실험에 사용한 흑마늘은 경남 남해군에서 재배 수확된 마늘 을 이용하여 새남해농협흑마늘가공사업소에서 생산된 것을 진공추출기로 $90^{\circ} \mathrm{C}$ 에서 12 시간 추출하여 각각 2,7 및 14 brix 로 농도 조정된 것을 제공받아 사용하였다.

\section{실험동물의 사양관리}

실험동물은 생후 4 주된 $160 \pm 10 \mathrm{~g}$ 의 Sprague-Dawley계 수 컷 성장기 흰쥐를 (주)샘타코(Seoul, Korea)로부터 분양 받아, 온도 $22 \pm 2{ }^{\circ} \mathrm{C}$, 습도 $50 \pm 5 \%$, 명암주기 12 시간(07:00 19:00)이 자동설정 된 동물 사육실에서 1주간 시판 고형사료(Rat chow, Samyang Co. Ltd.)로 적응시켰다. 기본식이로 1 주일간 예비사 육한 후 외관상 건강한 $180 \pm 10 \mathrm{~g}$ 흰쥐를 체중에 따른 난괴법으
로 6 마리씩 그룹으로 나누어 사육 상자에 한 마리씩 넣어 4 주 간 실험식이를 급이하면서 사육하였다.

\section{실험식이의 조성}

흑마늘 추출물의 농도에 따른 항스트레스 활성 평가를 위하 여 비구속정상군(Normal group, C), 구속군은 대조군(Control group, RC), 2 brix 흑마늘추출물 급이군(RT1), 7 brix 흑마늘 추출물 급이군(RT2), 14 brix 흑마늘추출물 급이군(RT3)으로 나누어 Table 1과 같은 식이 조성에 따라 식이에 혼합 급이하 였다.

\section{식이섭취량, 식이효율 및 체중측정}

실험기간 동안 식이는 매일 오후 5시에 급이하였고 다음날 오전 10 경에 식이섭취량을 조사하였다. 식이섭취량의 오차를 최소화하고자 손실량을 보정하였다.

물은 수도수를 공급하였으며 매일 신선하게 공급하였다. 체 중은 1 주일에 한번씩 일정한 시간에 측정하였다. 식이효율은 실험기간 동안의 체중 증가량을 같은 기간 동안의 총 식이섭 취량으로 나누어 산출하였다.

\section{스트레스 부과 및 실험동물의 처리}

4 주간의 실험식이를 거친 흰쥐의 스트레스 부과를 위하여 24 시간 동안 절식시킨 다음 구속케이지 $(15 \mathrm{~cm} \times 15 \mathrm{~cm} \times 20$ $\mathrm{cm})$ 에 한 마리씩 넣고 실온 $\left(24 \pm 2^{\circ} \mathrm{C}\right)$ 에서 24 시간 절식절수 상 태로 방치하였다.

24시간 구속스트레스를 가한 흰쥐는 에테르로 가볍게 마취 시켜 심장에서 채혈하였다. 채혈된 혈액은 빙수 중에서 30 분 간 냉각시킨 후 원심분리기(Mega 17R, Hanil, Korea)로 1,008 $g$ 에서 15 분간 원심분리 시켜 혈청을 얻어 $-70^{\circ} \mathrm{C}$ 에 보관해 두고 분석용 시료로 사용하였다.

Table 1. Composition of experimental diets for black garlic extracts fed rats

(g/100 g diet)

\begin{tabular}{|c|c|c|c|c|c|c|}
\hline Ingredient $^{1)}$ & Group & $\mathrm{C}$ & $\mathrm{RC}$ & RT1 & RT2 & RT3 \\
\hline Starch & & 39.74 & 39.74 & 39.74 & 39.74 & 39.74 \\
\hline Casein & & 20 & 20 & 20 & 20 & 20 \\
\hline Dextrin & & 13.2 & 13.2 & 13.2 & 13.2 & 13.2 \\
\hline Cellulose & & 5 & 5 & 5 & 5 & 5 \\
\hline Sucrose & & 10 & 10 & 10 & 10 & 10 \\
\hline Vitamin Mix. $^{2)}$ & & 1 & 1 & 1 & 1 & 1 \\
\hline Mineral Mix." & & 3.5 & 3.5 & 3.5 & 3.5 & 3.5 \\
\hline L-Cystein & & 0.3 & 0.3 & 0.3 & 0.3 & 0.3 \\
\hline Choline bitartrate & & 0.2 & 0.2 & 0.2 & 0.2 & 0.2 \\
\hline \multirow{3}{*}{ Black Garlic Extract (BGE) } & 2 brix & - & - & $1 \%$ & - & - \\
\hline & 7 brix & - & - & - & $1 \%$ & - \\
\hline & 14 brix & - & - & - & - & $1 \%$ \\
\hline
\end{tabular}

${ }^{1)} \mathrm{AIN}-96^{\mathrm{TM}}$ diet composition

${ }^{2)} \mathrm{AIN}-76^{\mathrm{TM}}$ Vitamin mixture

${ }^{3)} \mathrm{AIN}-76^{\mathrm{TM}}$ Mineral mixture 
실험동물의 장기(간장, 심장, 신장, 비장, 고환)는 채혈 후 즉시 분리시켰으며, 생리식염수로 혈액을 씻은 다음 흡수지로 물기를 제거하였고, 간은 탈혈하여 흡수지로 물기를 제거하고 무게를 측정한 후 $-70^{\circ} \mathrm{C}$ 에 보관하였다.

\section{혈당분석}

혈당 함량은 glucose 측정용 kit시약(AM 201-k, Asan, Korea)으로 측정하였다. 즉 효소시약을 효소시약 용해액에 용 해시킨 후 혈청 $20 \mu \mathrm{l}$ 에 조제한 효소시약 $3 \mathrm{ml}$ 를 첨가한 후 $37^{\circ} \mathrm{C}$ 에서 5 분간 배양한 후 시료 무첨가구를 대조로 하여 파장 $500 \mathrm{~nm}$ 에서 흡광도를 측정하였다. 혈당 함량은 표준검량선에 의해 $\mathrm{mg} / \mathrm{dl}$ 로 표시하였다.

\section{혈액 중 지질 함량 분석}

혈액 중의 총 지질(total lipid) 함량은 Frings 등[8]의 방법에 따라 혈청 $20 \mu \mathrm{l}$ 에 phospho-vanillin 시약을 첨가한 후 $37^{\circ} \mathrm{C}$ 에 서 15 분간 배양한 후 시료 무첨가구를 대조로 하여 파장 540 $\mathrm{nm}$ 에서 흡광도를 측정하였다. 혈액 중의 총 콜레스테롤(total cholesterol), 중성지방(triglyceride) 및 high density lipoprotein cholesterol (HDL-C) 함량은 각각의 해당 kit를 사용 하여 측정하였다. 즉, 총 콜레스테롤 측정용 $\mathrm{kit}$ 시약(AM 202-k, Asan, Korea), 중성지방 측정용 kit시약(AM 157S-k, Asan, Korea) 및 HDL-C 측정용 kit시약(AM 203-k, Asan, Korea)을 사용하여 혈청중의 함량을 측정하였다.

LDL (Low density lipoprotein) 콜레스테롤은 Friedewald 등[7]의 방법에 따라 총콜레스테롤 함량에서 HDL 콜레스테롤 과 중성지질/ 5 를 합한 값을 제하여 줌으로써 산출하였다. VLDL (Very Low density lipoprotein) 콜레스테롤 함량은 혈 청 총 콜레스테롤- (HDL-C+LDL-C)의 식으로 산출하였다[4]. 동맥경화지수(atherogenic index, $\mathrm{AI}$ )는 Haglund 등[10]의 방 법에 따라 (Total cholesterol - HDL-C)/ HDL-C식에 의하여, 심혈관 위험지수(cardiac risk factor, $\mathrm{CRF}$ )는 Kang 등[12]의 방법에 따라 총콜레스테롤 함량을 $\mathrm{HDL}$ 콜레스테롤 함량으로 나눈 값으로부터 산출하였다.

GOT (glutamic oxaloacetic transaminase)와 GPT (glutamic pyruvic transaminase) 활성도, 총단백질 및 알 부민 함량 측정

GOT 측정용 kit (PIII 3150, Fugi, Japan) 및 GPT 측정용 kit (PIII 3250, Fugi, Japan)를 이용하여 혈액분석기(DRIChem 3500I, Fugi, Japan)에서 분석하였으며, 혈청 $1 \mathrm{ml}$ 당 Karmen unit로 표시하였다.

혈중 총 단백질 함량은 총 단백질 측정용 kit (AM54-1011, Asan, Korea) 시약으로, 알부민의 함량은 BCG법에 따라 albumin 측정용 kit (AM 127, Asan, Korea) 시약으로 측정하 였다.

\section{간장 조직 내 지질성분의 분석}

간장 조직의 지질 함량은 Floch 등[6]의 방법에 따라 간조직 $0.5 \mathrm{~g}$ 에 chloroform : methanol 혼합액(C:M=2:1, v/v)을 가하 여 Poter-Elvehjem tissue grinder (DAIHAN WOS01010, Korea)로 마쇄하여 $30 \mathrm{ml}$ 로 정용한 다음 냉암소에 하룻밤 정 치시켜 지질을 추출하였다. 이를 여과(Whatman No. 7)하여 일정량을 취하여 건고시킨 것을 사용하였으며, 간조직의 지질 은 총 지질, 총 콜레스테롤 및 중성지방을 상기의 분석방법에 따라 측정하였다.

\section{간장 조직내 지질과산화물 함량 측정}

Uchiyama와 Mihara [28]의 방법에 따라 분석하였다. 즉, 간 조직 $1 \mathrm{~g}$ 에 $1.5 \% \mathrm{KCl}$ 용액을 가하여 homogenizer로 마쇄하여 $10 \%$ 균질액을 만든 다음, 이를 $0.5 \mathrm{ml}$ 를 취하여 $3 \mathrm{ml}$ 의 $1 \%$ phosphoric acid와 $1 \mathrm{ml}$ 의 $0.6 \% \mathrm{TBA}$ 를 넣어 잘 혼합하였다. 이것을 $95^{\circ} \mathrm{C}$ 수욕상에서 45 분간 가열한 뒤 $4 \mathrm{ml}$ 의 butanol를 가하여 발색물질을 추출한 다음 $3,000 \mathrm{rpm}$ 에서 10 분간 원심분 리한 butanol층의 흡광도 $\left(\mathrm{OD}_{535-520)}\right.$ 를 측정하였다. 간장조직의 TBARS 함량은 표준용액으로 1,1,3,3-tetraethoxypropane을 사 용한 표준 검량선으로부터 산출하였다.

\section{간장 조직의 글리코겐 함량 측정}

간 글리코겐의 함량 측정은 간조직의 $0.2 \mathrm{~g}$ 을 취해 $30 \%$ $\mathrm{KOH} 1 \mathrm{ml}$ 를 첨가한 후 $100^{\circ} \mathrm{C}$ 의 수욕상에서 20 분간 가열한 후 얼음으로 냉각을 하였다. 여기에 $95 \% \mathrm{EtOH} 1.25 \mathrm{ml}$ 를 첨가 하여 혼합한 후 $100^{\circ} \mathrm{C}$ 수욕상에서 5 분간 가열한 후 얼음으로 식힌다. 여기에 상층액을 버린 후 침전물에 증류수를 $5 \mathrm{ml}$ 가하 여 침전물을 용해시킨 다음 이 용액을 $0.5 \mathrm{ml}$ 를 취하고 4.5 $\mathrm{ml}$ 의 증류수를 가한 후 잘 혼합하여 $1 \mathrm{ml}$ 를 취한다. 여기에 $0.2 \%$ anthrone 용액을 $2 \mathrm{ml}$ 를 첨가를 하여 $100^{\circ} \mathrm{C}$ 의 수욕상에 서 10 분간 가열을 한 후 식혀서 $620 \mathrm{~nm}$ 에서 흡광도 값을 측정 하였다.

\section{통계처리}

반복 실험하여 얻은 결과는 SPSS 12.0 package를 사용하 여 분산분석 하였으며, 결과는 평균표준편차로 나타내었 다. 각 시료의 분석결과에 대한 유의성 검정은 분산분석을 한 후 $p<0.05$ 수준에서 Duncan's multiple range test를 실 시하였다.

\section{결과 및 고찰}

\section{식이효율 및 장기중량}

흑마늘 추출물의 농도를 달리하여 사료에 첨가 급이한 흰쥐 의 식이효율과 장기무게를 측정한 결과는 각각 Table 2와 3에 나타내었다. 총식이 섭취량은 $522.30 \pm 16.96 \sim 547.64 \pm 13.99$ 
$\mathrm{g} / 4$ weeks의 범위로 흑마늘 추출물의 농도가 증가할수록 식 이 섭취율은 증가하였으나 스트레스 대조군, 흑마늘 추출물 2 brix 및 7 brix 급이군 사이에는 유의적인 차이가 없었고 흑마늘 추출물 14 brix 급이군은 $547.64 \pm 13.99 \mathrm{~g} / 4$ weeks로 총식이 섭취량이 가장 많았다.

간장의 무게는 정상군이 $5.41 \pm 0.42 \mathrm{~g} / 100 \mathrm{~g}$ body weight인 데 비해 7 및 14 brix 흑마늘 추출물 첨가 급이군에서는 $5.03 \pm 0.93$ 및 $5.04 \pm 0.51 \mathrm{~g} / 100 \mathrm{~g}$ body weigh로 다소 낮았으나 통계적인 유의차는 없었다. 심장의 무게는 간장의 무게와 상 반되는 경향으로 대조군에서는 $0.64 \pm 0.31 \mathrm{~g} / 100 \mathrm{~g}$ body weight였으나 흑마늘 추출물 첨가 급이군에서는 $0.73 \pm 0.10 ~$ $0.83 \pm 0.13 \mathrm{~g} / 100 \mathrm{~g}$ body weight로 무게가 다소 증가하였다. 그러나 이러한 무게의 변화는 단순 평균값을 비교하였을 경우 에 한정되며, 모든 장기에서 흑마늘 추출물의 첨가 급이에 따 른 무게의 변화는 통계적인 유의차는 없었다.

\section{혈당 함량}

흑마늘 추출물을 농도를 달리하여 $1 \%$ 씩 각각 4 주 동안 급이 후 구속 스트레스를 가한 후 흰쥐의 혈당 함량을 조사한 결과 는 Fig. 1에 나타낸 바와 같이 정상군의 혈당은 $127.74 \pm 5.77$ $\mathrm{mg} / \mathrm{dl}$ 였으며, 구속대조군의 혈당은 $148.39 \pm 7.70 \mathrm{mg} / \mathrm{dl}$ 로 가 장 높았다. 흑마늘 추출물 첨가 급이군의 혈당은 흑마늘 추출 물의 농도가 높아질수록 낮아지는 경향을 보여 2 brix 추출물 급이군의 혈당은 $142.97 \pm 6.51 \mathrm{mg} / \mathrm{dl}$ 였으나 14 brix 급이군에

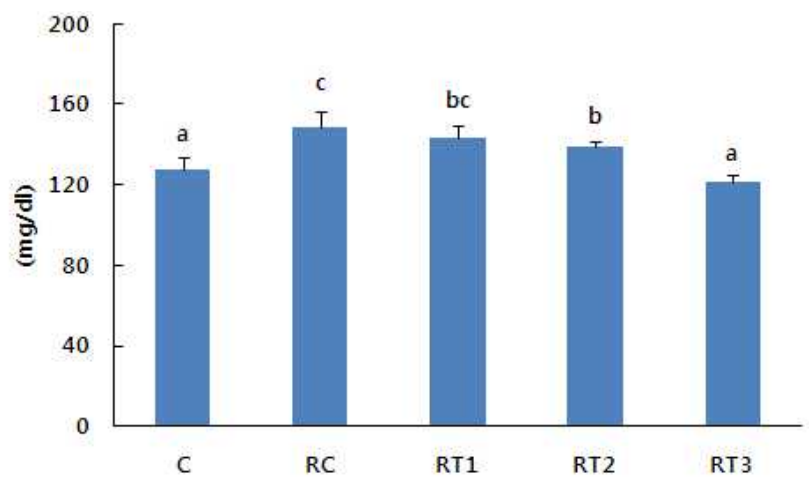

Fig. 1. Effect of black garlic extract on glucose level in serum of restraint stressed rat. ${ }^{1)}$ Refer to the Table $1 .{ }^{2)}$ Values are mean $\pm \mathrm{SD}(n=5) .{ }^{3)}$ Values in a column sharing the same superscript letter are not significantly different at $p<0.05$.

서는 $121.32 \pm 3.50 \mathrm{mg} / \mathrm{dl}$ 로 정상군 보다도 더 낮았다.

생체가 스트레스를 받게 되면 교감신경계가 흥분하게 됨으 로서 nore-epinepharine과 epinephrine의 분비가 증가하게 되 며 이로 인해 혈압상승이 발생하고 심장박동이 증가하게 되 며, 혈당수치는 상승하고, 호흡은 빨라지게 된다[16]. 본 실험 의 결과 대조군의 혈당에 비해 구속대조군의 혈당이 유의적으 로 높은 것은 구속에 따른 신체적, 신경적 스트레스가 원인이 된 것으로 판단된다. 또, 흑마늘 추출물의 급이로 혈당이 유의 적으로 감소됨에 따라 흑마늘 추출물의 급이는 구속 스트레스

Table 2. Total food intake, body weight gain and food efficiency ratio(FER) of black garlic extract fed rats

\begin{tabular}{lccc}
\hline Group $^{1)}$ & Total food intake $(\mathrm{g} / 4$ weeks $)$ & Total body weight gain $(\mathrm{g} / 4$ weeks $)$ & FER \\
\hline C & $522.30 \pm 16.96^{\mathrm{a} 2 / 3)}$ & $146.70 \pm 25.64^{\mathrm{ab}}$ & $0.28 \pm 0.04^{\mathrm{NS} 4)}$ \\
RC & $538.60 \pm 9.33^{\mathrm{ab}}$ & $161.71 \pm 13.57^{\mathrm{b}}$ & $0.30 \pm 0.22$ \\
RT1 & $536.48 \pm 19.87^{\mathrm{ab}}$ & $145.38 \pm 26.83^{\mathrm{ab}}$ & $0.27 \pm 0.04$ \\
RT2 & $533.88 \pm 21.76^{\mathrm{ab}}$ & $138.23 \pm 15.71^{\mathrm{a}}$ & $0.26 \pm 0.04$ \\
RT3 & $547.64 \pm 13.99^{\mathrm{b}}$ & $148.14 \pm 20.21^{\mathrm{ab}}$ & $0.27 \pm 0.03$ \\
\hline
\end{tabular}

${ }^{1)}$ Refer to the Table 1 .

${ }^{2)}$ Values are mean \pm SD $(n=5)$.

${ }^{3)}$ Values in a column sharing the same superscript letter are not significantly different at $p<0.05$.

${ }^{4)} \mathrm{NS}$ : not significant.

Table 3. The organ weight of liver, heart, kidney, spleen and testis in black garlic extract fed rats

(tissue g/100 g body weight)

\begin{tabular}{lccccc}
\hline Group $^{1)}$ & Liver & Heart & Kidney & Spleen & Testis \\
\hline C & $5.41 \pm 0.42^{2 \text { NS3) }}$ & $0.64 \pm 0.31^{\text {NS }}$ & $1.54 \pm 0.16^{\text {NS }}$ & $0.42 \pm 0.07^{\text {NS }}$ & $2.39 \pm 0.29^{\text {NS }}$ \\
RC & $5.48 \pm 0.43$ & $0.66 \pm 0.07$ & $1.37 \pm 0.15$ & $0.38 \pm 0.04$ & $2.04 \pm 0.08$ \\
RT1 & $5.43 \pm 1.64$ & $0.83 \pm 0.13$ & $1.47 \pm 0.23$ & $0.37 \pm 0.07$ & $2.11 \pm 0.29$ \\
RT2 & $5.03 \pm 0.93$ & $0.81 \pm 0.14$ & $1.46 \pm 0.28$ & $0.41 \pm 0.07$ & $2.04 \pm 0.34$ \\
RT3 & $5.04 \pm 0.51$ & $0.73 \pm 0.10$ & $1.45 \pm 0.17$ & $0.38 \pm 0.05$ & $2.22 \pm 0.22$ \\
\hline
\end{tabular}

${ }^{1)}$ Refer to the Table 1.

${ }^{2)}$ Values are mean \pm SD $(n=5)$.

${ }^{3)} \mathrm{NS}$ : not significant. 
에 따른 혈당의 증가를 저지할 수 있으며, 그 농도가 높을수록 더 효과적임을 확인할 수 있었다.

혈청 지질 농도 및 동맥경화지수와 심혈관 위험지수의 산출 항스트레스 흑마늘 음료를 개발하기 위해 흑마늘 추출물 농도를 달리하여 흰쥐에 급이시킨 후 스트레스 개선 효능을 조사하기 위하여 흰쥐에 24시간 구속 스트레스를 부과한 다음 혈청을 분리하여 총 콜레스테롤 중성지질의 농도를 측정한 결과는 Table 4 에 나타내었다.

총 콜레스테롤 함량은 $54.54 \pm 1.63 \sim 65.84 \pm 2.61 \mathrm{mg} / \mathrm{dl}$ 의 범 위였는데, 구속대조군에서 가장 높은 함량이었으며, 구속 스 트레스를 부과하지 않은 정상군의 혈청 총콜레스테롤 함량은 $59.13 \pm 1.89 \mathrm{mg} / \mathrm{dl}$ 였다. 2 brix 및 7 brix 흑마늘 추출물 첨가 급이군의 혈중 총콜레스테롤 함량은 구속대조군 보다 낮았으 며, 정상군과는 통계적인 유의차가 없었다. 14 brix의 흑마늘 추출물 첨가 급이군의 혈청 총 콜레스테롤 농도는 $54.54 \pm 1.63$ $\mathrm{mg} / \mathrm{dl}$ 로 가장 낮은 함량이었으며, 정상군에 비해서도 유의적 으로 낮은 함량이었다.

중성지질의 함량도 총 콜레스테롤의 함량과 동일한 경향으 로 구속대조군이 $44.35 \pm 2.67 \mathrm{mg} / \mathrm{dl}$ 로 가장 높은 함량이었으 며, 정상군과 흑마늘 추출물 2 및 7 brix 첨가 급이군은 $30.22 \pm 1.56 \sim 33.47 \pm 2.10 \mathrm{mg} / \mathrm{dl}$ 의 범위로 통계적인 유의차가 없었다. 흑마늘 추출물을 14 brix 첨가 급이군의 혈청 중성지 질 농도는 $25.02 \pm 2.46 \mathrm{mg} / \mathrm{dl}$ 로 가장 낮았다.

Wang 등[29]은 홍삼에서 total antioxidant capacity과 radical scavenging activity는 비슷한 수준인데, 미국산 홍삼에서 항산화 활성의 증가는 Maillard 반응 생성물에 기인하며, 인삼 의 열처리 과정 중에 이러한 물질 중의 하나인 maltolo이 생성 되고 phenolic compounds가 풍부해지면서 강한 free radical scavenging 활성을 가지는 것으로 보고 한 바 있다.

마늘도 흑마늘로 생성되는 단계에서 Calamel화 반응, Maillard 반응 등의 비효소적갈변반응과 Polyphenoloxidase (PPS)와 같은 효소적 갈변 등 다양한 갈변현상이 일어난다 [13]. 또한 흑마늘은 갈변물질 증가와 함께 폴리 페놀류의 함량 이 증가하며 S-allyl-cysteine이라는 수용성의 유황아미노산이 증가되어, 생마늘보다 항산화력이 상승하고, 암 예방, 콜레스
테롤 저하, 동맥경화 개선작용을 한다고 보고되어 있다[25]. 이러한 보고들로 미루어 볼 때 흑마늘 추출물 첨가 급이군 의 혈청 콜레스테롤 및 중성지질의 감소에는 흑마늘에 함유된 갈변물질들이 주로 기여할 것으로 판단된다.

$\mathrm{HDL}$-콜레스테롤 농도는 정상군에서 $38.18 \pm 1.61 \mathrm{mg} / \mathrm{dl}$ 로

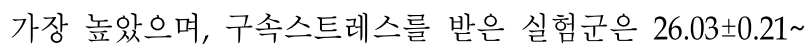
$31.60 \pm 1.18 \mathrm{mg} / \mathrm{dl}$ 로 정상군에 비해 유의적으로 낮았다. 7 brix 및 14 brix 흑마늘 추출물 첨가 급이군의 혈청 HDL-콜레스테 롤 농도는 각각 $31.60 \pm 1.18 \mathrm{mg} / \mathrm{dl}$ 와 $31.39 \pm 0.72 \mathrm{mg} / \mathrm{dl}$ 로 통 계적인 유의차는 없었다.

LDL-콜레스테롤은 정상군이 $14.26 \pm 3.87 \mathrm{mg} / \mathrm{dl}$ 인데 비해 구속대조군은 $36.38 \pm 3.24 \mathrm{mg} / \mathrm{dl}$ 로 가장 높은 농도였으며, 흑 마늘 추출물의 농도가 증가할수록 LDL-콜레스테롤의 농도는 유의적으로 감소하여 $14 \mathrm{brix}$ 흑마늘 추출물 첨가 급이군에서 $17.14 \pm 2.54 \mathrm{mg} / \mathrm{dl}$ 로 가장 낮은 함량이었다.

VLDL-콜레스테롤 또한 LDL-콜레스테롤과 동일한 경향으 로 구속대조군이 $30.38 \pm 3.24 \mathrm{mg} / \mathrm{dl}$ 로 가장 높았으며, 정상군 이 $13.33 \pm 5.07 \mathrm{mg} / \mathrm{dl}$ 로 가장 낮은 함량이었다. VLDL-콜레스 테롤의 농도는 흑마늘 추출물을 급이 하지 않고 24 시간 구속 스트레스를 가한 구속대조군이 정상군에 비해 2.2배 증가한 데 반해 흑마늘 추출물을 첨가 급이군에서는 $18.94 \pm 1.24$ $21.37 \pm 5.81 \mathrm{mg} / \mathrm{dl}$ 의 범위로 정상군보다는 1.4 1.6배 정도 증 가하여, 흑마늘 추출물의 급이가 VLDL-콜레스테롤의 농도를 저하에 기여함을 확인할 수 있었다.

주로 동맥경화 및 심장순환계 질환의 발병위험도를 알리는 위험지수로 널리 이용이 되는 동맥경화지수(AI) 및 심혈관질 환 위험지수(CRF)를 환산한 결과 구속대조군이 $1.16 \pm 0.11$ 및 $2.63 \pm 0.11$ 로 가장 높게 산출되었으며 흑마늘 추출물을 농도별 로 섭취한 군은 이보다 유의적으로 낮았다. Framingham heart study에서는 동맥경화 지수가 3.5 이하이면 관상동맥질 환의 발생위험으로부터 안전한 수준이며, 적어도 4.5 이하를 유지하도록 권장하고 있다[3].

최근, 녹차, 감자, 양파와 같은 식물성 폴리페놀 화합물이 많이 들어 있는 식품의 섭취량이 많을수록 심장 순환계 질환 에 의한 사망률과 암으로 인한 사망률이 낮다는 여러 임상적 역학조사 결과가 있어서 이들 물질의 유효성이 더욱 주목 받

Table 4. Effect of black garlic extract on lipid profiles in serum of restraint stressed rat

\begin{tabular}{|c|c|c|c|c|c|c|c|}
\hline Group $^{1)}$ & $\begin{array}{l}\text { Total cholesterol } \\
(\mathrm{mg} / \mathrm{dl})\end{array}$ & $\begin{array}{l}\text { Triglyceride } \\
(\mathrm{mg} / \mathrm{dl})\end{array}$ & HDL-C & $\frac{\text { LDL-C }}{(\mathrm{mg} / \mathrm{dl})}$ & VLDL-C & $\begin{array}{l}\text { Atherogenic } \\
\text { index (AI) }\end{array}$ & $\begin{array}{l}\text { Cardiac risk } \\
\text { factor (CRF) }\end{array}$ \\
\hline C & $59.13 \pm 1.89^{2) b 3)}$ & $33.47 \pm 2.10^{b}$ & $38.18 \pm 1.61^{d}$ & $14.26 \pm 3.87^{\mathrm{a}}$ & $13.33 \pm 5.07^{\mathrm{a}}$ & $0.55 \pm 0.11^{\mathrm{a}}$ & $1.55 \pm 0.11^{\mathrm{a}}$ \\
\hline RC & $65.84 \pm 2.61^{c}$ & $44.35 \pm 2.67^{\mathrm{c}}$ & $26.03 \pm 0.21^{\mathrm{a}}$ & $36.38 \pm 3.24^{\mathrm{d}}$ & $30.38 \pm 3.24^{c}$ & $1.16 \pm 0.11^{\mathrm{d}}$ & $2.63 \pm 0.11^{\mathrm{d}}$ \\
\hline RT1 & $61.31 \pm 2.09^{b}$ & $30.22 \pm 1.56^{\mathrm{b}}$ & $28.40 \pm 0.33^{\mathrm{b}}$ & $24.04 \pm 2.41^{\mathrm{c}}$ & $21.37 \pm 5.81^{b}$ & $0.88 \pm 0.19^{b c}$ & $1.88 \pm 0.19^{b c}$ \\
\hline RT2 & $58.24 \pm 2.72^{b}$ & $30.38 \pm 3.28^{b}$ & $31.60 \pm 1.18^{\mathrm{c}}$ & $21.37 \pm 5.81^{\mathrm{bc}}$ & $18.94 \pm 1.24^{\mathrm{ab}}$ & $0.70 \pm 0.08^{\mathrm{ab}}$ & $1.70 \pm 0.08^{\mathrm{ab}}$ \\
\hline RT3 & $54.54 \pm 1.63^{\mathrm{a}}$ & $25.02 \pm 2.46^{\mathrm{a}}$ & $31.39 \pm 0.72^{c}$ & $17.14 \pm 2.54^{\mathrm{ab}}$ & $21.70 \pm 4.70^{\mathrm{b}}$ & $1.04 \pm 0.23^{c}$ & $2.04 \pm 0.23^{c}$ \\
\hline
\end{tabular}

${ }^{1)}$ Refer to the Table 1.

${ }^{2)}$ Values are mean \pm SD $(n=5)$.

${ }^{3)}$ Values in a column sharing the same superscript letter are not significantly different at $p<0.05$. 
고 있는 실정이다[14].

본 실험에서도 흑마늘을 급이함으로 인해 구속스트레스를 가한 흰쥐의 $\mathrm{AI}$ 지수가 구속대조군에 비해 낮았던 것으로 보아 흑마늘 추출물을 급이함으로써 다양한 스트레스에 노출된 상 황에서도 동맥경화와 같은 혈관계 질환의 예방 및 개선에 도 움이 될 것으로 판단된다.

\section{GOT 및 GPT의 정량}

24시간 구속하여 스트레스를 가한 흰쥐의 혈청 GOT 및 GPT의 함량을 Table 5에 나타내었다. 혈청 중의 지질량은 대 부분 간 대사에 의해 생기므로 식이성 원인 이외에도 간 기능 과 밀접한 관련이 있다. GPT는 각종 간질환(예로 급만성 간염, 약물 또는 알코올성 중독, 간염, 간 경변, 폐쇄성황달, 간암)에 보다 특이적으로 그 농도가 상승하는데 반해 GOT는 간성질환 이외에도 심장, 신장, 골격, 근육과 같은 여러 장기의

침해 시 심근경색과 진행성 디스트로피 등을 유발함으로써 활성도가 상승한다. 정상인의 GOT 활성도는 $5 \sim 40 \mathrm{u} / 1$ 인데 정상 흰쥐 $(50$ $90 \mathrm{u} / \mathrm{l})$ 는 이보다 더 높고, 정상인의 GPT 활성 도는 7 56 u/1이고 정상 흰쥐는 이보다 낮아 5 40 u/1라고 알려져 있다[22].

혈청 GOT 및 GTP의 농도는 모두 동일한 경향으로 정 상군이 가장 낮았고 구속대조군이 가장 높은 함량이었으 며 흑마늘 추출물을 섭취한 군은 이 두 값의 중간 범위로 흑마늘 추출물의 농도가 높아질수록 효소의 활성도가 더 낮았다.

특히 구속대조군의 GOT는 정상군에 비해 1.4 배 정도 상승 한 $121.80 \pm 2.49 \mathrm{unit} / \mathrm{ml}$ 의 농도로 측정되었는데 흑마늘 추출

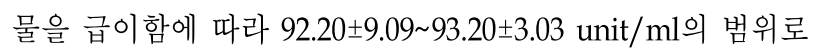
측정되어 위에서 흑마늘 추출물의 섭취에 따른 간보호 효과가 있었을 것으로 추측된다.

\section{혈청 중 총 단백질 및 알부민의 함량}

혈청 중의 단백질(total protein) 및 알부민(albumin)의 함량

Table 5. Effect of black garlic extract on GOT and GPT in serum of restraint stressed rat

(Karmen unit/ml)

\begin{tabular}{lcc}
\hline Group $^{1)}$ & GOT & GPT \\
\hline C & $85.60 \pm 3.85^{\mathrm{a} 23) 3}$ & $10.38 \pm 0.18^{\mathrm{a}}$ \\
RC & $121.80 \pm 2.49^{\mathrm{c}}$ & $18.30 \pm 1.29^{\mathrm{d}}$ \\
RT1 & $93.20 \pm 3.03^{\mathrm{b}}$ & $15.85 \pm 1.05^{\mathrm{c}}$ \\
RT2 & $92.20 \pm 9.09^{\mathrm{b}}$ & $14.38 \pm 1.01^{\mathrm{bc}}$ \\
RT3 & $92.80 \pm 5.89^{\mathrm{b}}$ & $12.96 \pm 0.43^{\mathrm{b}}$ \\
\hline
\end{tabular}

${ }^{1)}$ Refer to the Table 1 .

${ }^{2)}$ Values are mean \pm SD $(n=5)$.

${ }^{3)}$ Values in a column sharing the same superscript letter are not significantly different at $p<0.05$.
을 분석한 결과는 Table 6 과 같다. 총 단백질 함량은 구속대조 군이 $9.54 \pm 2.73 \mathrm{mg} / \mathrm{dl}$ 로 가장 높게 측정되었으며 농도별 흑마 늘 추출물 첨가급이군에서는 $6.76 \pm 0.33 \sim 8.42 \pm 1.22 \mathrm{mg} / \mathrm{dl}$ 의 범위로 구속대조군에 비해 유의적으로 낮은 함량이었다. 구속 스트레스를 받지 않은 정상군의 단백질 함량은 $7.53 \pm 1.43$ $\mathrm{mg} / \mathrm{dl}$ 로 흑마늘 추출물 2 brix 및 7 brix $1 \%$ 첨가 급이군과는 유의차가 없었으나, 14 brix의 흑마늘 추출물을 급이한 군에서 는 $6.76 \pm 0.33 \mathrm{mg} / \mathrm{dl}$ 로 유의적으로 낮은 함량이었다. 본 실험 의 결과 스트레스를 가한 군이 정상군보다 그 함량이 높은 것은 절식 및 절수의 조건에서 24 시간 구속 스트레스를 부과 함에 따라 체내 대사를 위하여 체 단백의 분해가 급속히 진행 되었기 때문으로 추정된다.

알부민은 간에서 합성되는 혈액 단백질로 혈장 총 단백의 $60 \%$ 정도를 차지할 정도로 중요하며 중증 간질환에서는 감소 되므로 중요 간 질환 기능성 지표로 이용되고 있다[15]. 24시간 구속스트레스를 가한 흰쥐의 알부민을 측정한 결과 정상군보 다 구속대조군의 알부민의 함량이 $5.33 \pm 1.16 \mathrm{mg} / \mathrm{dl}$ 로 가장 높았고, 흑마늘 추출물 7 및 14 brix 첨가 급이군에서는 각각 $4.93 \pm 0.55 \mathrm{mg} / \mathrm{dl}$ 와 $3.84 \pm 0.40 \mathrm{mg} / \mathrm{dl}$ 로 정상군 $(4.21 \pm 1.63$ $\mathrm{mg} / \mathrm{dl}$ 과 통계적인 유의차가 없었다.

\section{간장의 총 지질, 총 콜레스테롤과 중성지질의 함량}

24 시간 구속시킨 흰쥐의 간장 중 지질성분을 추출하여 총 지질, 총 콜레스테롤 및 중성지질의 함량을 분석한 결과는 Table 7과 같다. 간장 중의 총지질의 함량은 구속대조군에서 가장 높았고 그 다음으로 흑마늘 추출물 2 brix 첨가 급이군과 정상군의 순이었으나 이 두 실험군 사이에는 유의차가 없었 다. 흑마늘 추출물 7 brix 및 14 brix 첨가 급이군의 간장 중 총 지질 함량은 각각 $25.49 \pm 3.73 \mathrm{mg} / \mathrm{g}$ wet liver과 $26.00 \pm 5.38$ $\mathrm{mg} / \mathrm{g}$ wet liver로 정상군 보다도 낮은 함량이었으며, 두 실험 군 간에는 통계적인 유의차가 없었다.

총 콜레스테롤 함량은 $5.28 \pm 0.40 ~ 4.19 \pm 0.67 \mathrm{mg} / \mathrm{g}$ wet liver 의 농도로 측정되었는데 흑마늘 추출물의 첨가 급이 없이 구

Table 6. Effect of black garlic extract on total protein and albumin contents in serum of restraint stressed rat

\begin{tabular}{lll}
\hline Group $^{1)}$ & Total protein & Albumin \\
\hline C & $7.53 \pm 1.43^{\mathrm{ab} 23)}$ & $4.21 \pm 1.63^{\mathrm{abc}}$ \\
RC & $9.54 \pm 2.73^{\mathrm{b}}$ & $5.33 \pm 1.16^{\mathrm{c}}$ \\
RT1 & $8.42 \pm 1.22^{\mathrm{ab}}$ & $3.02 \pm 0.17^{\mathrm{a}}$ \\
RT2 & $7.60 \pm 0.84^{\mathrm{ab}}$ & $4.93 \pm 0.55^{\mathrm{bc}}$ \\
RT3 & $6.76 \pm 0.33^{\mathrm{a}}$ & $3.84 \pm 0.40^{\mathrm{ab}}$ \\
\hline
\end{tabular}

${ }^{1)}$ Refer to the Table 1.

${ }^{2)}$ Values are mean \pm SD $(n=5)$.

${ }^{3)}$ Values in a column sharing the same superscript letter are not significantly different at $p<0.05$. 
Table 7. Effect of black garlic extract on total lipids, total cholesterol and triglyceride contents in liver of restraint stressed rat (mg/g wet liver)

\begin{tabular}{llcc}
\hline Group $^{1)}$ & Total lipids & Total cholesterol & Triglyceride \\
\hline C & $28.34 \pm 7.47^{\text {b2)3 }}$ & $4.19 \pm 0.67^{\mathrm{a}}$ & $16.88 \pm 1.71^{\mathrm{ab}}$ \\
RC & $37.99 \pm 7.86^{\mathrm{c}}$ & $5.28 \pm 0.40^{\mathrm{b}}$ & $18.36 \pm 1.29^{\mathrm{b}}$ \\
RT1 & $31.35 \pm 4.37^{\mathrm{b}}$ & $4.97 \pm 0.73^{\mathrm{ab}}$ & $16.59 \pm 1.19^{\mathrm{a}}$ \\
RT2 & $25.49 \pm 3.73^{\mathrm{a}}$ & $4.79 \pm 0.65^{\mathrm{ab}}$ & $15.73 \pm 1.05^{\mathrm{a}}$ \\
RT3 & $26.00 \pm 5.38^{\mathrm{a}}$ & $4.64 \pm 0.52^{\mathrm{ab}}$ & $16.18 \pm 0.94^{\mathrm{a}}$ \\
\hline
\end{tabular}

${ }^{1)}$ Refer to the Table 1.

${ }^{2)}$ Values are mean \pm SD $(n=5)$.

${ }^{3)}$ Values in a column sharing the same superscript letter are not significantly different at $p<0.05$.

속 스트레스를 부과한 구속대조군에서 가장 높은 함량이었으 며 정상군에서 가장 낮은 함량이었다. 흑마늘 추출물 첨가 급 이군의 간장 중 총 콜레스테롤 함량은 $4.64 \pm 0.52 ~ 4.97 \pm 0.73$ $\mathrm{mg} / \mathrm{g}$ wet liver으로 서로 간에 유의적인 차이가 없었으며, 정상군 및 구속대조군과도 차이가 크지 않았다.

간장 중 중성지질의 농도는 총 지질 및 총 콜레스테롤 농도 와 유사한 경향을 보였는데 정상군 $(16.88 \pm 1.71 \mathrm{mg} / \mathrm{g}$ wet liv$\mathrm{er})$ 에 비해 구속스트레스를 가함으로서 간장 중성지질은 $8.6 \%$ 증가하였는데, 흑마늘 추출물을 첨가 급이 한 군에서는 구속 대조군에 비해 유의적으로 낮은 함량이었으며, 흑마늘 추출물 의 농도 차이에 따른 간장 중성지질의 농도에는 유의적인 차 이가 없었다.

\section{간장 중 TBARS의 함량}

24시간 구속스트레스를 가한 흰쥐의 간장 내 지질과산화물 생성 정도를 측정하고자 TBARS의 함량을 측정한 결과는 Fig. 2에 나타내었다. 간장 내 지질과산화물 생성은 구속대조군이 $4.37 \pm 0.25 \mathrm{mmol} / \mathrm{g}$ wet liver로 가장 많은 과산화물이 생성되 었으며 그 다음으로 흑마늘 추출물 2 brix 첨가 급이군의 순이

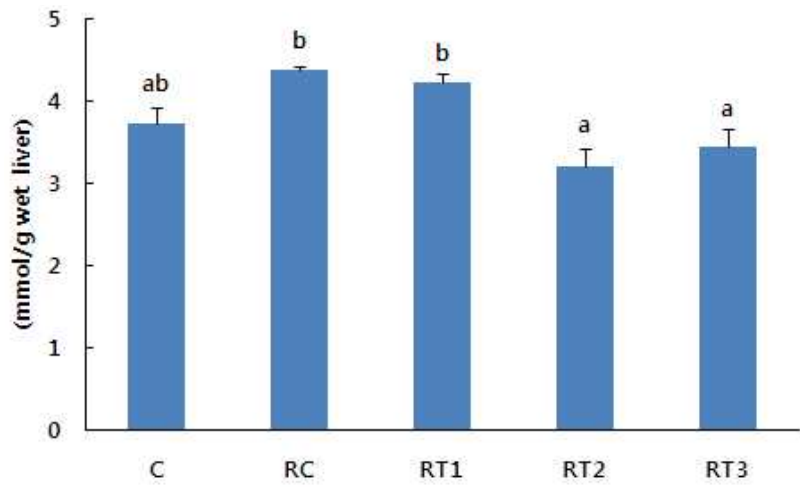

Fig. 2. Effect of black garlic extract on TBARS content in liver of restraint stressed rat. ${ }^{1)}$ Refer to the Table $1 .{ }^{2)}$ Values are mean \pm SD $(n=5) .{ }^{3)}$ Values in a column sharing the same superscript letter are not significantly different at $p<0.05$.
었다. 흑마늘 추출물의 농도가 낮을 때는 구속스트레스로 인 한 지질과산화물의 생성정도를 낮추지는 못했지만 흑마늘 추 출물의 농도가 증가할수록 간장 내 지질과산화물은 정상군보 다 유의적으로 낮은 함량이었으며, 7 brix 흑마늘 추출물 급이 시는 정상군에 비해 $8.4 \%$ 나 낮은 농도였다.

Allium속 식물류에 함유된 플라보노이드는 항산화 효소 활 성의 증가 및 직접적인 유리 라디칼 제거제로 작용하여 체내 과산화지질 생성을 억제함으로써 조직을 보호하는 것으로 알 려져 있다[9]. Shin과 $\mathrm{Kim}$ [27]은 마늘의 항산화 활성이 마늘에 함유된 총 페놀, 플라보노이드, 항산화 비타민 등에 의한 상호 작용에 의한 것으로 보고한 바 있다.

\section{간장 중 글리코겐의 함량}

근육의 무산소 운동에서 글리코겐이 사용되지만 유산소운 동에서 지방산의 효율적인 산화를 위하여 필요한 옥살로 아세 트산을 생산할 글리코겐이 필요하기 때문에 간과 근육의 글리 코겐 축척은 지구력 증진 및 운동효율을 높여준다고 알려져 있으며 지구성 운동 수행능력을 저해하는 영양학적인 요소는 크게 저장 글리코겐과 저혈당증의 두 가지로 구분할 수 있다.

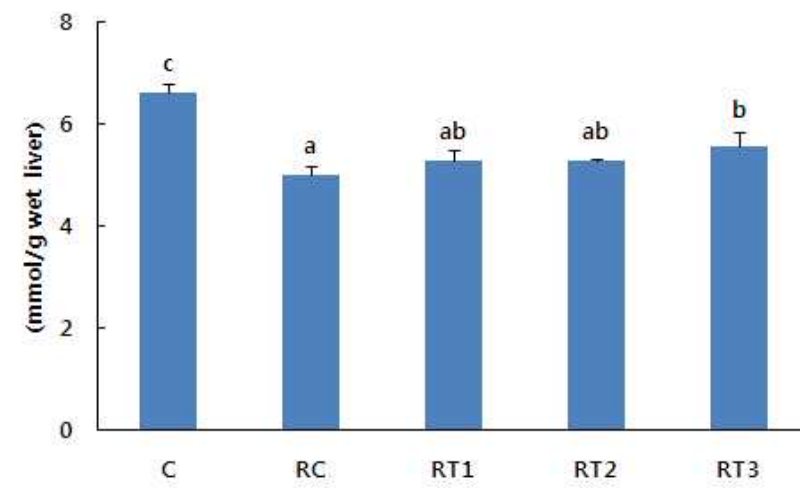

Fig. 3. Effect of black garlic extract on glycogen content in liver of restraint stressed rat. ${ }^{1)}$ Refer to the Table $1 .{ }^{2}$ Values are mean $\pm \mathrm{SD}(n=5) .{ }^{3)}$ Values in a column sharing the same superscript letter are not significantly different at $p<0.05$. 
실제로 운동을 장시간 계속하게 되면 체내에 제한적으로 존재 하는 글리코겐은 감소하거나 고갈되며, 이러한 현상이 피로를 유발시켜 근 운동이나 지구성 운동을 제한하는 중요한 요인으 로 작용하게 된다[19].

농도가 다른 흑마늘 추출물을 4 주간 급이한 흰쥐의 간장 글리코겐 함량을 분석한 결과는 Fig. 3과 같으며 간장 중의 글리코겐 함량은 장시간의 구속으로 인해 비구속군에 비해 유의적으로 감소하였으며 구속대조군은 $4.98 \pm 0.20 \mathrm{mmol} / \mathrm{g}$ wet liver으로 가장 낮은 함량이었다. 흑마늘 추출물을 첨가 급이한 군의 간장 글리코겐 함량은 2 brix와 7 brix 농도 급이 시는 구속대조군과 통계적인 유의차가 미미하였으나, 14 brix 흑마늘 추출물 급이시는 $5.54 \pm 0.68 \mathrm{mmol} / \mathrm{g}$ wet liver로 정상 군보다는 낮은 함량이었으나 구속대조군에 비해서는 더 높은 함량이었다.

\section{References}

1. Ames, B. N., Shigenaga, M. K. and Hagen, T. M. 1993. Oxidant, antioxidant and the degenerative disease of aging. Proc. Natl. Acad Sci. USA 90, 7915-7922.

2. Aronne, L., Nelinson, D. and Lillo, J. 2009. Obesity as a disease state: A new paradigm for diagnosis and treatment. Clin. Cornerstone 9, 9-29.

3. Castelli, W. P., Garrison, R. J., Wilson, P. W. F., Abborr, R. D., Kalousdian, S. and Kannel, W. B. 1986. Incidence of coronary heart disease and lipoprotein cholesterol leavels. The Framingham Study JAMA 256, 2835-2845.

4. Cheung, P. C. K. 1998. Plasma and hepatic cholesterol levels and fecal neutral sterol extcretion are alter in hamsters fed straw mushroom diets. J. Nutr. 128, 1512-1530.

5. Choi, D. J., Lee, S. J., Kang, M. J., Cho, H. S. and Sung, N. K. 2008. Physicochemical characteristics of black garlic (Allium sativum L.). J. Korean Soc. Food Nutr. 37, 465-471.

6. Folch, J., Lees, M. and Stanley, G. H. 1957. A simple method for the isolation and purification of total lipids from animal tissues. J. Biol. Chem 226, 497-502.

7. Friedewald, W. T., Levy, R. I. and Fredrickson, D. S. 1972. Estimation of the concentration of low density lipoprotein cholesterol in plasma, without use of the preparative ultracentrefuge. Clin. Chem 18, 499-502.

8. Frings, C. S., Fendley, T. W., Dunn, R. T. and Queen, C. A. 1972. Improved determination of total serum lipids by the sulfo-phospho-vanillin reaction. Clin. Chem 18, 763-764.

9. Haenen, G. R., Paquay, J. B., Korthouwer, R. E. and Best, A. 1997. Peroxynitrite scavenging by flavonoids. Biochem Biophys Res. Commun. 236, 591-593.

10. Haglund, O., Loustarinen, R., Wallin, R., Wibell, I. and Saldeen, T. 1991. The effect of oil on triglycerides, cholesterol, fibrinogen and malondi- aldehyde in mand supplemented with vitamin. Eur. J. Nutr. 121, 165-172.

11. Hong, M. S. 1992. The culture of food in Korea. pp. 79. Kyomoonsa, Seoul.
12. Kang, S. M., Shim, J. Y., Hwang, S. J., Hong, S. G., Jang, H. E. and Park, M. H. 2003. Effects of Saengshik supplementation on health improvement in diet-induced hypercholesterolemic rats. J. Korean Soc. Food Sci. Nutr. 32, 906-912.

13. Kim, H. K., Jo, K. S., Shin, D. E. and Kim, I. H. 1987. Effect of phosphate complex treatment on the quality of dried garlic flakes. Korean J. Food Sci. Tochnol. 19, 75-80.

14. Knekt, P., Jarvinen, R., Reunanen, A. and Martela, J. 1997. Flavonoid intake and coronary mortality in Finland : a cohort study. Br. Med J. 312, 478-481.

15. Koo, K. B., Chung, J. M. and Lee, H. S. 1998. Biochemical evaluation of nutritional status of protein and lipid in patients with alcoholic liver disease. J. Korean Soc. Food Sci. Nutr. 27, 1236-1243.

16. Lim, S. H., Jeong, H. Y., Won, H. Y., Kim, H. W., Choi, C. W., Jeong, H. S., Kim, Y. G. and Cho, S. I. 2012. Effects of Banhahubak-tang Extract on Psychological Stress. Kor. J. Herbology 27, 81-88.

17. Medina-Campos, O. N., Barrera, D., Segoviano-Murillo, S. Rocha, D., Maldonado, P., Mendoza-Patin, N. and Pedraza-Chaverri, J. 2007. S-allylcysteine scavenges singlet oxygen and hypochlorous acid and protects LLC-PK1 cells of potassium dichromate-induced toxicity. Food Chem Toxicol. 45, 2030-2039.

18. Orth Gom, K., Moser, V., Blom, M., Wamala, S. P. and Schenck Gustafesson, K. 1997. Survey of stress in women. Heart disease in Stockholm women is caused by both family-and-work-related stress. Lakartidningen. 632, 635-638.

19. Pirnay, F., Scheen, A. J., Gautier, J. F., Lacroix, M. and Mosora, F. 1995. Exogenous glucose oxidation during exercise in relation to the power output. Int. J. Sports Med 16, 456-460.

20. Raju, J. and Mehta, R. 2009. Cancer chemopreventive and therapeutic effects of diosgenin, a food saponin. Nutr. Cancer 61, 27-35.

21. Rona, C. and Berardesca, E. 2008. Aging skin and food supplements: the myth and the truth. Clin Dermatd. 26, 641-647.

22. Sheo, H. J. 1999. Effect of garlic on the blood lipids and other serum components in rats. J. Korean Soc. Food Sci. Nutr. 28, 1339-1348.

23. Shin, J. H., Choi, D. J., Chung, M. J., Kang, M. J. and Sung, N. K. 2008. Changes of physicochemical components and antioxidant activity of aged garlic at different temperatures. J. Korean Soc. Food Sci. Nutr. 37, 1174-1181.

24. Shin, J. H., Choi, D. J., Lee, S. J., Cha, J. Y. and Sung, N. J. 2008. Antioxidant activity of black garlic (Allium sativum L.). J. Korean Soc. Food Sci. Nutr. 37, 965-971.

25. Shin, J. H., Jung, K. M., Lee, S. J., Yang, S. M., Rue, G. H. and Sung, N. J. 2009. Biological activities of dried garlic, red ginseng and their mixutre. J. Korean Soc. Food Sci. Nutr. 38, 1633-1639.

26. Shin, J. H., Lee, H. G., Kang, M. J., Lee, S. J. and Sung, N. J. 2010. Antioxidant activity of solvent fraction from black garlic. J. Korean Soc. Food Sci. Nutr. 39, 933-940.

27. Shin, S. H. and Kim, M. K. 2004. Effect of dried powders or ethanol extracts of garlic flesh and peel on antioxidative 
capacity in 16-mouth-old rats. Korean J. Nutr. 37, 633-644.

28. Uchiyama, M. and Mihara, M. 1978. Determination of malondialdehyde precursor in tissues by TBA test. Anal. Biochem 86, 271-278.
29. Wang, M. F., Shao, Y. J., Yi, G., Zhu, N. Q., Rngarajan, M., Lavoie, E. J. and Ho, C. T. 1998. Antioxidative phenolic compounds from sage (Salivia officinalis). J. Agric. Food Chem 46, 4869-4873.

\section{초록 : 구속스트레스를 가한 흰쥐의 지질 대사에 대한 흑마늘 추출물의 효과}

\section{강민정 · 신정혜*}

(남해마늘연구소)

흑마늘의 구속 스트레스에 대한 유효농도를 확인하고자 2, 7 및 14 brix로 조절한 흑마늘 추출물을 급이한 흰쥐 의 체내 지질대사를 중심으로 분석하였다. 흑마늘 추출물 14 brix 급이군의 식이섭취량은 $547.64 \pm 13.99 \mathrm{~g} / 4$ weeks로 대조군에 비해 유의적으로 높았다. 모든 장기에서 흑마늘 추출물의 첨가 급이에 따른 무게의 변화는 통계적인 유의차는 없었다. 흑마늘 추출물 첨가 급이군의 혈당은 흑마늘 추출물의 농도가 높아질수록 낮아지는 경향을 보여 2 brix 추출물 급이군의 혈당은 $142.97 \pm 6.51 \mathrm{mg} / \mathrm{dl}$ 였으나 $14 \mathrm{brix}$ 급이군에서는 $121.32 \pm 3.50 \mathrm{mg} / \mathrm{dl}$ 로 정상군 보다도 더 낮았다. 총 콜레스테롤 함량은 $54.54 \pm 1.63 ~ 65.84 \pm 2.61 \mathrm{mg} / \mathrm{dl}$ 의 범위였는데, $14 \mathrm{brix}$ 의 흑마 늘 추출물 첨가 급이군의 혈청 총 콜레스테롤 농도는 $54.54 \pm 1.63 \mathrm{mg} / \mathrm{dl}$ 로 가장 낮은 함량이었으며, 정상군에 비 해서도 유의적으로 낮은 함량이었다. 중성지질의 함량도 동일한 경향이었다. HDL-콜레스테롤 농도는 구속대조 군에 비해 흑마늘 추출물 7 및 14 brix 급이군에서 유의적으로 높았으며, LDL VLDL-콜레스테롤은 이와 상반되는 결과를 나타내었다. 혈청 GOT 및 GTP 활성도는 흑마늘 추출물의 농도가 높아질수록 낮아져 흑마늘 추출물의 급이는 간보호 활성을 나타낼 것으로 기대된다. 간장내 총 지질 및 중성지질의 함량은 구속대조군에 비해 흑마늘 추출물 급이군에서 유의적으로 낮았으나 총콜레스테롤은 서로간에 유의차가 없었다. 간장내 지질 과산화물인 TBARS 함량은 2 brix의 흑마늘 추출물 급이군은 구속대조군과 유의적인 차이가 없었으나 7 및 14 brix 급이군은 정상군보다 더 낮은 함량이었다. 간장내 글리코겐 함량은 구속대조군에 비해 14 brix 흑마늘 추출물 급이군에서 만 유의적으로 낮았다. 이상의 결과들을 종합하여 볼 때 7 brix 이상의 흑마늘 추출물 급이는 흰쥐의 지질대사를 개선하고, 간보호 활성을 나타냄으로써 구속 스트레스로 해소에 기여할 것으로 추정된다. 